\title{
EROSION OF THE CONCEPT OF CONSTITUTIONAL SUPREMACY IN MALAYSIA
}

\author{
Noor 'Ashikin Hamid ${ }^{1}$ \\ Faculty of Law and International Relations, \\ Universiti Sultan Zainal Abidin, (UniSZA) Malaysia \\ (Email: shikin@unisza.edu.my) \\ Kamaliah Salleh ${ }^{2}$ \\ Faculty of Law and International Relations, \\ Universiti Sultan Zainal Abidin, (UniSZA) Malaysia \\ (Email: kamaliahsalleh@unisza.edu.my)

\section{Noraida Harun ${ }^{3}$} \\ Faculty of Law and International Relations, \\ Universiti Sultan Zainal Abidin, (UniSZA) Malaysia \\ (Email: noraida@unisza.edu.my)

\section{Asiah Bidin ${ }^{4}$} \\ Faculty of Law and International Relations, \\ Universiti Sultan Zainal Abidin, (UniSZA) Malaysia \\ (Email: asiah@unisza.edu.my) \\ Nazli Ismail @ Nawang 5 \\ Faculty of Law and International Relations, \\ Universiti Sultan Zainal Abidin, (UniSZA) Malaysia \\ (Email: inazli@unisza.edu.my)
}

Accepted date: 22-02-2019

Published date: 10-07-2019

To cite this document: Hamid, N. A., Salleh, K., Harun, N., Bidin, A., \& Ismail Nawang, N. (2019). Erosion of the Concept of Constitutional Supremacy in Malaysia. International Journal of Law, Government and Communication, 4(15), 27-35.

DOI: $10.35631 / \mathrm{ijlgc.} 415004$

\begin{abstract}
The concept of constitutional supremacy is provided by Article 4 (1) and 162(6) of the Malaysian Federal Constitution. It is differed from the doctrine of supremacy of Parliament as practised in English jurisprudence. The objective of this paper is to study the concept of constitutional supremacy, why it has become very important and the dangers that it poses if there is an erosion of the concept. The study is based on doctrinal research as it is primarily concerned with the review of the provisions of the Constitution and reported cases that have been decided by the courts. It is suggested that it was possible for Parliament to amend the Constitution to a point where it basically may defect the concept of constitutional supremacy in Malaysia.
\end{abstract}

Keywords: Constitutional, Supremacy, Erosion 


\section{Introduction}

Wheare (1966) defined constitution as the whole system of government of a country, the collection of rules which establish and regulate or govern the government. Barendt (1998) defined it as a power map which organized political authority so that the power will not be used oppressively and arbitrarily. Merriam-webster.com. dictionary (n.d) defines constitution as the fundamental and organic law of a nation or state that establishes the institutions and apparatus of government, defines the scope of governmental sovereign powers, and guarantees individual civil rights and civil liberties. In Malaysia the term constitution is used in two senses; firstly, as a body of legal and non-legal rules concerning the government of a state; and secondly as a single document having special legal status, which established the state, and sets out the structure and powers of the state (Hamzah, 2009). Supremacy, on the other hand is defined as the position of having the superior or greatest power or authority. From the foregoing, it can be seen that constitutional supremacy is the position of the constitution having the superior or greatest power or authority.

\section{Literature Review}

\section{The Concept of Constitutional Supremacy}

The concept of constitutional supremacy is provided by Articles 4(1) and 162(6) of Federal Constitution (hereafter is referred to as the Constitution) as well as section 73 of Malaysia Act 1963. This concept had also been affirmed in the case of Ah Thian v Government of Malaysia (1976) which states: "The doctrine of the supremacy of Parliament does not apply in Malaysia. Here we have a written Constitution. The power of Parliament and the State Legislatures in Malaysia is limited by the Constitution and they cannot make any law they please" (p. 113). Article 4(1) of the Constitution refers only to laws made after Merdeka Day which states that: "This Constitution is the supreme law of the Federation and any law passed after Merdeka Day which is inconsistent with the Constitution shall, to that extent of inconsistency be void". On the other hand, Article 162(6) of the Constitution refers to the laws made before Merdeka Day. According to the case of Datuk Seri Samy Vellu v Nadarajah (2001) the different approach taken by Article 4(1) and 162(6) of Federal Constitution is in the former, any post-Merdeka law which is inconsistent with the Constitution shall be declared void to the extent of the inconsistency while in the latter, any pre-Merdeka law which is inconsistent with the Constitution shall be continued with the necessary modifications to render it consistent with the Constitution.

In Malaysia supremacy of the constitution is maintained through judicial review by the courts. There are two forms of judicial review: the first one is traditionally known as the ultra vires rule/vires-based theory (Craig, 1988). It involves reviewing the discretionary actions of the executive in applying statutory regulations, as well as review of executive action for compliance with the common law and other restraints such as reasonableness and fairness. The second form of judicial review recognize the supremacy of a written constitution which legitimates the higher courts to review primary legislation in order to test its conformity or compatibility with a written constitution. Accordingly, legislation may be invalidated on one of the following grounds (Hamzah, 2009): firstly: the Federal Court has exclusive jurisdiction to declare a legislation to be invalid based on Article 128(1) of Federal Constitution. In this sense, the Federal Court has jurisdiction to determine any question whether a law made by Parliament or the Legislature of the State is invalid on the ground that it makes provision with respect to a matter with respect to which Parliament or, as the case may be, the Legislature of the State has no power to make laws. Secondly: it has not been enacted in accordance with the procedure prescribed in the constitution. Thirdly: it is inconsistent with any provision of the 
constitution. Lastly: in the case of state law, it is inconsistent with federal law. Article 75 of Federal Constitution states that the federal law shall prevail if any state law is inconsistent with a federal law and the state law shall be void to the extent of inconsistency.

\section{Erosion of Constitutional Supremacy}

Although the concept of supremacy claimed to apply in Malaysia, the erosion of the concept does occur in reality due to the following factors: firstly: the special powers of Parliament to legislate to counter emergency and subversion (Hamzah, 2009). Secondly: the ease with which constitutional amendments have been achieved since independence (Hamzah, 2009). Thirdly: judicial attitudes in the interpretation of the Constitution (Hamzah, 2009) and lastly: safeguards and caveats contained in the Inter-Government Committee (IGC) and the Malaysia Agreement 1963.

As regard to the first factor, emergency laws passed during emergency are considered valid even if they are inconsistent with provisions in the Constitution, except for a limited scope of matters, during emergency. These exceptions are only applicable to matters related to religion, citizenship, language, Malay customs, and native law or customs in Sabah and Sarawak, as specified in Article 150 (6A) of the constitution. Fundamental liberties such as freedom of movement, freedom of speech, assembly and association guaranteed under our constitution can be suspended during emergency. For example, the Emergency (Public Order and Prevention of Crime) Ordinance 1969 allows for detention without trial indefinitely. In addition, the federal government can make laws that are under a state's jurisdiction such as on land matters during emergency, as provided under Article 150 (4) of the constitution. Further, Article 150(7) of the Constitution states that emergency ordinances and legislation shall cease to have any effect six months after the end of the emergency. The effect is that emergency law may exist until the emergency is revoked or in the event of ordinances not revoked or annulled at that point, the emergency law may remain in existence for a further six months. While Article 149 provides for the possibility of the passing of legislation which permit the violation of fundamental rights contained in Articles 5 (relating to personal liberty), 9 (relating to prohibition of banishment and freedom of movement), 10 (relating to freedom of speech, assembly and association) and 13 (relating to rights of property) on the ground of subversion. 'Subversion' has been defined in Article 149 (1) to refer to the following: causing people to fear organised violence; exciting disaffection against the government; promoting feelings of ill-will between classes of the population in such a way as is likely to cause violence; procuring alteration, otherwise than by lawful means of anything by law established; prejudicing the maintenance of any supply or service to the public; or causing prejudice to public order or national security. It is evident that this definition of subversion 'is of such a broad catch-all nature that even vigorous criticism of official polices, industrial action like strikes and call to taxpayers to withhold payment could conceivably fall within the parameters of subversion (Tikamdas, 2003).

Regarding to the second factor, amendment of the Constitution is provided for in Article 159. Clause (1) declares that, "Subject to the following provisions of this Article and to Article $161 \mathrm{E}$, the provisions of this Constitution may be amended by federal law". The Article then prescribes four different methods for amendment of the different provisions of the Constitution: some parts of the Constitution require a majority of two-thirds in both Houses of Parliament: Article 159 (3); some parts may be amended by a simple majority in both Houses of Parliament, such as that required for the passing of any ordinary law: Article 159(4); some parts may be amended by a two-thirds majority in both Houses of Parliament and the consent of the Conference of Rulers: Art 159(5); and, some parts require a two-thirds majority in both Houses of Parliament and the consent of the governor of the East Malaysian state in 
question: Article 161E. Certain provisions in the constitution may not be practical or relevant as the time advanced due to the occurrence of changes in social, political and economic and hence, an amendment to the certain provisions need to be done by the legislative so that it still relevant. The Reid Commission (1957) suggested that:

"Amendments should be made by Act of Parliament provided that an Act to amend the Constitution must be passed in each House by a majority of at least two-thirds of the members voting. In this matter, the House of Representatives should not have the power to overrule the Senate. We think that this is a sufficient safeguard for the States because the majority of members of the Senate will represent the States" (para. 80).

In short this type of amendment is a common method of an amendment and most of the Constitution provisions are amended by this method. It allows the amendment of the basic structure of the constitution like democracy, federalism or separation of powers. Mohamad (2017) mentioned that the Constitution may be amended by a two-thirds majority in both Houses of Parliament and, in certain cases, with the consent of the Conference of Rulers. In short he said that the power to amend the Constitution is vested in the Parliament; nowhere does it say that certain articles form the basic structure of the Constitution and cannot be amended and nowhere does it say that the court may decide on a case to case basis which articles form part of the basic structure of the Constitution or not and, therefore, may or may not be amended. It is the Parliament that has the power to amend any part of the Constitution provided it follows the right procedure as provided by the Constitution as to the extend it may amend the basic structure of the Constitution (if any).

Current development in Semenyih Jaya Sdn Bhd v Land Administrator of the District of Hulu Langat (2017) the Federal Court however held otherwise. The fact in that case is that the Land Acquisition Act 1960 (the Act) provides for the legal process by which the government may compulsorily acquire land held in private ownership. Initially, the Act vested the power to determine appeals (by way of a procedure called "land reference") against the value determined by the Land Administrator to compulsorily acquired land in a judge of the High Court. Later, Parliament made several amendments to the Act and inserted s 40D. By this amendment, the judge was to be assisted by two professional land valuers. The amendment also removed the judge's power to determine the value of the land and vested it in the assisting valuers. The appellant whose land was acquired under the amended procedure challenged the constitutionality of this amendment. The Federal Court held that s 40D was unconstitutional as it purports to corrode the judicial power of the judiciary. The court even went further to hold that the constitutional amendment of 1988 was void as the judicial power is a basic structure of the Federal Constitution that cannot be taken away by Parliament. Later it was held in Indira Gandhi v The Director of Islamic Affairs Perak (2018) that the features of the basic structure cannot be abrogated or removed by a constitutional amendment. Yunus (2018) argued that with the basic structure doctrine, our constitutional framework and its essential features may be maintained and the three branches of government, i.e. the executive, the judiciary and parliament, kept within their constitutional limits.

The third factor leads to erosion of constitutional supremacy is related with constitutional interpretation. The court may declare it ultra vires and void if a legislative or executive act violates the constitution. The courts have to interpret the text of the Constitution and expound the concepts compressed in a concise language in carrying out this task. Some provisions of the Constitution because of the clear meaning of the text do not require the application of a sophisticated theory of constitutional interpretation in order to reach a conclusion. On the other 
hand, there are provisions of the Constitution where the text itself is abstract or ambiguous that analysis of information from outside of the constitutional text such as an examination of the history, structure, purpose and intent of the relevant provision, is necessary. In Federal Court decision of Dato 'Menteri Othman bin Baginda \& Anor v Dato Ombi Syed Alwi bin Syed Idrus (1981) per Raja Azlan Shah Ag LP (as he then was):

In interpreting a constitution two points must be borne in mind. First, judicial precedent plays a lesser part than is normal in matters of ordinary statutory interpretation. Secondly, a constitution, being a living piece of legislation, its provisions must be construed broadly and not in a pedantic way -- 'with less rigidity and more generosity than other Acts' (see Minister of Home Affairs v Fisher [1980] AC 319). A constitution is sui generis, calling for its own principles of interpretation, suitable to its character, but without necessarily accepting the ordinary rules and presumptions of statutory interpretation. As stated in the judgment of Lord Wilberforce in that case: 'A constitution is a legal instrument given rise, amongst other things, to individual rights capable of enforcement in a court of law. Respect must be paid to the language which has been used and to the traditions and usages which have given meaning to that language. It is quite consistent with this, and with the recognition that rules of interpretation may apply, to take as a point of departure for the process of interpretation a recognition of the character and origin of the instrument, and to be guided by the principle of giving full recognition and effect to those fundamental rights and freedoms'. The principle of interpreting constitutions 'with less rigidity and more generosity' was again applied in the Privy Council in Attorney-General of St Christopher, Nevis and Anguilla v Reynolds [1980] AC 637 (p. 32).

Generally speaking the rules of construction that guide a court in the interpreting of ordinary statutes applies equally when interpreting the Constitution. But there are important differences. For the Constitution, unlike any ordinary statute, does not merely declare the law. It creates and regulates the law-making power of federation. It also creates and defines the various branches of government. It confers upon individuals certain fundamental and inalienable human rights, such as equality before the law. Its language must accordingly receive a broad and liberal construction in order to advance the intention of its frames. Lord Diplok in AttorneyGeneral of the Gambia v Momodou Jobe (1984) said that: "A constitution, and in particular that part of it which protects and entrenches fundamental rights and freedoms to which all persons in the state are to be entitled, is to be given a generous and purposive construction" (p. 700). Therefore, a court, while rendering a broad and liberal construction to the language employed by the Federal court, is not entitled to stretch or pervert the language of enactment in the interests of any legal or constitutional theory, or even for the purpose of supplying omissions or of correcting supposed errors (per Gwyer CL in Re Central Provinces \& Berar Sales of Motor Spirit \& Lubricantw Taxation Act AIR 1939 FC 1). It means that the courts are given the right of judicial review and the task of interpreting the Constitution and judicial attitudes to constitutional interpretation changes as the time advanced. Judicial interpretation is a method in which the words of the constitutional provision do not change but their meaning undergoes a change resulting from interpretation by the court (Hamzah, 2009).

Fourth the studying of the Intergovernmental Committee (Great Britain and Federation of Malaya) Report (hereafter is referred to as IGC Report) 1962 and the Malaysia Agreement 1963 it was revealed that the provisions of both documents may defect the concept of constitutional supremacy in Malaysia. Failing to understand the safeguards and caveats in the IGC Report and the subsequent Malaysia Agreement 1963 is perhaps the reason that many people perceive the Malaysia Constitution as supreme; however not many people understand 
that the supremacy of the Constitution is limited by the safeguards and caveats contained in the IGC and the Malaysia Agreement 1963. Among privileges are that entry into Sabah and Sarawak should require the approval of the State Government. The Federal Government should not be able to veto the entry of persons into Sabah and Sarawak for State Government purposes except on strictly security grounds. Sabah and Sarawak should have unfettered control over the movements of persons other than those in Federal Government employ from other parts of Malaysia into Sabah and Sarawak. Even when amendments are made in the Constitution and approved by a 2/3 majority in Parliament, these amendments shall not be affective in Sabah and Sarawak unless it is approved by the government of the Borneo States. There must be no new Enactments which touch the state rights as contained in Schedule 9 of the Constitution can be enforced in Sabah and Sarawak unless it is approved by the governments of Sabah and Sarawak (ZainnalAjamain, 2014).

\section{Finding}

There have been approximately more than fifty amending acts and 700 individual textual amendments made to the Constitution since its enactment in 1957 (Tham, 2007). The Constitution confers on the government broad powers under Article 150 to proclaim emergency if the government is satisfied that a grave emergency exits whereby the security, or the economic life, or public order, in the Federation or any part thereof is threatened. The scope of emergency was expanded by the Privy Council in Stephen Kalong Ningkan v Government of Malaysia (1968) which said that "an emergency is not confined to unlawful use or threat of force in any of its manifestations... [but] is capable of covering a very wide range of situations and occurrences" (p. A514). In 1981, Article 150 was amended so that a proclamation can be issued before the actual occurrence of threatened event, by way of prevention action, if the government is satisfied that there is imminent danger of its occurrence. The immediate consequence of an emergency proclamation is that the government obtains the power under Article 150 to legislate by ordinances having the same effect as an Act of parliament, except when both Houses of parliament are sitting, and provided the government is satisfied that circumstances exist which render it necessary to take immediate action (Harding, 2012). Further, Harding (2012) contended that "this power extends to any matter with respect to which Parliament has power to make laws, regardless of the legislature or other procedures required to be followed, or the proportion of the total votes required to be had, in either House of Parliament" (p. 168). Parliament has the power to pass any emergency laws following a proclamation. The provisions of emergency laws cannot be invalidated on the ground of inconsistency with any provisions of the constitution, except those relating to Islamic religion, Malay customs and native custom in Sabah and Sarawak, religion, citizenship or language. At the same time any provision of legislation designed to stop subversion may be valid even if inconsistent with fundamental rights provided or contrary to the division of state and federal powers. It is under this provision that Parliament has passed preventive detention laws such as the Internal Security Act 1960 (ISA) and the Dangerous Drugs (Special Preventive Measures) Act 1985.

Hamzah (2009) observed that certain provisions in the constitution may not be practical or relevant as the time advanced due to the occurrences of changes in social, political and economic conditions, hence the amendment to certain provisions need to be done by the legislative. The Reid Commission framed it in such a way that an amendment would not be too difficult to the extent of frustrating the need for amendment, but at the same time, not too easy that it would end up weakening our constitutional safeguards (Hamid, N. A., Ismail Nawang, N., Salleh, K., Harun, N. and Bidin, A., 2017). However, Lee (1978) observed that a constitution which is extremely easy to amend for it may turn out to be worse than having no 
constitution at all. He observed that some of the more fundamental amendments to the Malaysian Constitution have led to "a truncation of safeguards which had been considered by the Reid Commission as vital for the growth of a viable democratic nation" ( p. 369). In short, the executive who controls two thirds or more of the seats in Parliament may amend any part of the Constitution even if the amendment cuts cross or even destroys the basic structure of the Constitution.

Besides, the Alliance party of Barisan Nasional had been attaining the majority seats in House of Representatives all this while till recently. The party had attained a two-thirds majority of the seats throughout its occupancy and hence, the amendments of most of the provision to the Constitution were done at ease and can be done according to their desire on how the amendments affect the people. However, in 2018 General Election, the Pakatan Harapan (PH) coalition, which had been the country's federal Opposition prior to the election, won a simple majority in the Dewan Rakyat together with the Sabah Heritage Party (WARISAN), with both PH and WARISAN cumulatively securing 121 seats (Suruhanjaya Pilihan Raya Malaysia, 2018). Barisan Nasional (BN) coalition, which had enjoyed an uninterrupted reign over the country since Malaya's independence in 1957, was voted out of power. Malaysia has 222 parliamentary seats and a simple majority to win the election is 112 seats, hence, the party would still be able to amend the provisions to the Constitution at ease. There might be a little bit of difficulty in passing an amendment of provisions to the Constitution due to objections from the opposition party, however it is actually still possible for Parliament to amend the Constitution to a point where it basically contradicted the spirit and intent with which the original Constitution was drawn up.

Previously, the judges adopted a 'hands-off' policy from 1957 and 1985 which is called as the period of judicial restraint. This means the judges restrain themselves to go beyond the literal interpretation of the Constitution. This conservative approach refused to conclude whether there are implied limitations on the power of constitutional amendment moreover in political matters (Hamzah, 2009). Besides, the judges tend to follow English's decision as their decisions were subject to appeal to the Privy Council rather than Indian decisions although Malaysian Constitution is more similar to Indian Constitution. This is also, due to, most of the Malaysian judges received legal training in the United Kingdom which causes them to be more familiar to parliamentary sovereignty compared to constitutional supremacy. Until today judges are not consistent or predictable in its methods; sometimes the Constitution is treated as if it were like an ordinary statute, while at the other time is given an expansive interpretation (Harding, 2012). Consequently, there are possibilities that judges may come out with the interpretation which defect the concept of constitutional supremacy in Malaysia.

Even when amendments are made in the Malaysia Constitution and approved by a two third majority in Parliament, these amendments shall not be affective in Sabah and Sarawak, unless it is approved by the government of the Borneo States. A clear example of limitation imposed on the Constitution by the IGC Report and Malaysia Agreement 1963 is the Immigration Act 1959/63. The Act was enacted to control the movement of people and the powers are given in the Federal List in Schedule 9 of the Constitution. However, the IGC Report is detailed in protecting the rights of the people in the Borneo States. As such the Immigration Act 1959/63 incorporates the powers of the Borneo states into the Act from section 62 to section 74 of that Act. In enforcing this law, the Director of Immigration in Sabah and Sarawak has no alternative when directed by the "State Authority" to stop a particular type of people from being allowed to enter Sabah and Sarawak. The fact that Article 5(1) of the Constitution provides for free movements in the Federation has no effect on it. Recently, there was a demand of an 
amendment to the Federal Constitution so that it can restore Sabah and Sarawak's status as equal partners in order to implement Malaysia Agreement 1963. It was argued that the current Article 1(2) of the Federal Constitution which was amended in 1976 downgraded Sabah and Sarawak as the 12th and 13th states instead of equal partners with Peninsular Malaysia (theStarOnline, 2018). Should the amendment is allowed, then it further weaken the concept of constitutional supremacy in Malaysia.

\section{Conclusion}

To conclude, people recognise however, that as circumstances change, so some change in the rules may become necessary or desirable. The procedure for constitutional change must strike a balance. It should not make it easy for the legislature or the executive to do away with constitutional limitations on governmental power at their whim. At the same time, it should not impede necessary or desirable change. In Malaysia, the executive controls a majority of seats in the legislature. Unless more stringent procedures than normal are required to be followed, the legislature and, in particular, the executive through its control of the legislature may easily amend the Constitution as to defect its supremacy.

\section{References}

Barendt, E. (1998). An introduction to constitutional Law-Clarendon Law Series. UK: OUP Oxford.

Craig, P.P. (1998). Ultra Vires and the foundation of judicial review. Cambridge Law Journal, 57, 63-90

Hamid, N. A., Ismail Nawang, N., Salleh, K., Harun, N. and Bidin, A. (2017). The doctrine of basic structure of the Malaysian constitution: A study of framework. Pertanika J. Soc. Sci. \& Hum. 25 (S), $163-170$.

Hamzah, W.A. (2009). A first look at the Malaysian legal system. Selangor: Oxford Fajar Sdn. Bhd.

Harding, A. (2012). The Constitution of Malaysia- A contextual analysis. Oregon: Hart Publishing.

Lee, H.P.(1998). The process of constitutional change. In Suffian, M., Lee, H. P. and Trindade, F. A. (Ed.), The Constitution of Malaysia - its Development: 1957-1977(pp. 369-392). Kuala Lumpur: Oxford University Press.

Ling, G.P. (2018). Spelling the end of emergency laws. SelangorTime. Retrieved from http://www.selangortimes.com/index.php?section=insight\&permalink=Spelling\%20th e\%20end\%20of\%20emergency\%20laws

Mohamad, A.H. (2017). Not for judges to rewrite constitution. New Straits Times. Retrieved from https://www.nst.com.my/opinion/columnists/2017/06/248725/not-judgesrewrite-constitution

Portal Rasmi Suruhanjaya Pilihan Raya Malaysia (SPR). (2018). Retrieved from www.spr.gov.my/

Supremacy. (2018). In Merriam-webster.com. Retrieved from https://www.merriamwebster.com/dictionary/supremacy

Tikamdas, R. (September 2003). National Security and constitutional rights - the Internal Security Act $1960 . \quad$ Infoline. Retrived from http://www.malaysianbar.org.my/human_rights/national_security_and_constitutional _rights_the_internal_security_act_1960.html

Tham, C. (July 2007). Major changes to the Constitution. The Sun. Retrieved from http://www.malaysianbar.org.my/echoes_of_the_past/major_changes_to_the_constitu tion.html. 
Ling, S. (2018). Law Minister: Constitutional amendment needed before Sabah and Sarawak can be restored as equal partners. The Star. Reterived from https://www.thestar.com.my/news/nation/2018/10/08/constitutional-amendmentneeded-before-sabah-and-sarawak-can-be-restored-as-equalpartners/\#WdbWqfqGklVCvF46.99

Wheare, K.C. (1966). Modern constitution. Oxford: Oxford University Press.

Yunus, M.H. (2018). Legal Herald. Selangor: Percetakan Jiwabaru Sdn. Bhd. Retrieved from https://www.lh-ag.com/wp-content/uploads/2018/12/1-The-Malaysian-Constitutionand-the-Basic-Structure-Doctrine.pdf

ZainnalAjamain. (2014). Limitations to supremacy of Malaysia Constitution. Suara Sabah. Retreived from https://suarasabah.wordpress.com/2014/03/01/limitations-to-supremacy-of-malaysiaconstitution/

(1963). Inter-governmental Committee (Great Britain and Federation of Malaya). Federation of Malaya: Government Printer.

(1957). Report of the Federation of Malaya Constitutional Commission 1957. London: Her Majesty's Stationary Office, Colonial No. 330

(2017). Federal Constitution (as at $1^{\text {st }}$ March 2017). Selangor: International Book Service.

Cases

Attorney-General of the Gambia v Momodou Jobe [1984] AC 689 (Gambia).

Ah Thian v Government of Malaysia 19762 MLJ 112 (MYS.).

Datuk Seri Samy Vellu v Nadarajah 20011 AMR 1 (MYS.).

Dato 'Menteri Othman bin Baginda \& Anor v Dato Ombi Syed Alwi bin Syed Idrus 19811 MLJ 29 (MYS.).

Indira Gandhi $v$ The Director of Islamic Affairs Perak 20181 MLJ 545 (FC) (MYS.).

Semenyih Jaya Sdn Bhd v Land Administrator of the District of Hulu Langat 20173 MLJ 561 (FC) (MYS.).

Stephen Kalong Ningkan v Government of Malaysia 1968 2MLJ 238 (MYS.). 